\title{
Concentrate Supplementation Reduces Postprandial Plasma Ghrelin in Grazing Dairy Cows: A Possible Neuroendocrine Basis for Reduced Pasture Intake in Supplemented Cows
}

\author{
J. R. Roche,$^{\star 1}$ A. J. Sheahan, $†$ L. M. Chagas, $†$ and D. P. Berrył \\ *University of Tasmania, P.O. Box 3523, Burnie, Tasmania 7320, Australia \\ †Dexcel Ltd., Hamilton, New Zealand \\ $\ddagger$ Teagasc, Moorepark Dairy Production Research Centre, Fermoy, Co. Cork, Ireland
}

\begin{abstract}
Ghrelin is an endogenous ligand of the growth hormone secretagogue receptor, and a potent orexigenic agent in human and rodent studies. We hypothesized that ghrelin may play a role in the reduced grazing time in dairy cows receiving supplementary feeds. Fiftyeight Holstein-Friesian (HF) dairy cows of New Zealand $(\mathrm{NZ} ; \mathrm{n}=28)$ and North American $(\mathrm{NA} ; \mathrm{n}=30)$ ancestry were provided with unrestricted access to pasture and randomly allocated at calving to either 0,3 , or $6 \mathrm{~kg}$ of dry matter concentrates in a $2 \times 3$ factorial arrangement. Concentrates were offered in equal amounts at each milking. In peak lactation (75 and $79 \pm 19.7 \mathrm{~d}$ in milk), blood was sampled from all cows prior to the a.m. milking (i.e., baseline) and following $2 \mathrm{~h}$ of unrestricted access to fresh pasture after the a.m. milking on 2 consecutive weeks. Daily milk yield and fat, protein, and lactose concentrations were measured on the day of blood sampling. North American cows produced more milk and consumed numerically more pasture than did NZ cows, and NA cows had elevated plasma ghrelin concentrations pre- and postfeeding. A negative association between dry matter intake and postprandial ghrelin concentrations indicated that other controlling factors may be involved. Circulating ghrelin concentrations before feeding were not affected by concentrate supplementation, but increasing supplementation was associated with a linear decline in pasture intake and postprandial ghrelin concentrations. This negative association between concentrate supplementation and plasma ghrelin concentrations offers a potential neuroendocrine basis for the reduced pasture intake when supplements are offered to cows in grazing systems.
\end{abstract}

Key words: ghrelin, Holstein-Friesian strain, pasture, concentrate supplementation

Received April 24, 2006.

Accepted November 11, 2006.

${ }^{1}$ Corresponding author: john.roche@utas.edu.au

\section{INTRODUCTION}

Few tasks executed by the brain hold greater survival value than maintaining or increasing DMI (Broberger, 2005). In no animal is this more true than in the dairy cow, where the demands of lactation result in considerable metabolic stress. Metabolic state can be reflected to the brain by a diverse array of signals (Broberger, 2005), such as through stimulation of the vagus nerve, or through adipose tissue derived hormones such as leptin and adiponectin (Seeley et al., 2004). An additional, and more recently discovered, mode of stimulation may be through ghrelin, an endogenous ligand for the growth hormone secretagogue receptor, and possibly the most powerful peripherally active orexigenic (appetite-stimulating) agent known (Kobelt et al., 2005).

Because of its orexigenic properties, ghrelin may play a role in the feeding behavior and energy homeostasis of dairy cows (Sugino et al., 2002), but to date there is a paucity of information characterizing changes in this hormone under different feeding regimens (Robinson et al., 2006). Studies by Sugino et al. (2002) and Hayashida et al. (2001) showed a preprandial surge in plasma ghrelin concentrations prior to feeding in both sheep and cattle, followed by a postprandial decrease. Roche et al. (2006b) reported a positive relationship between genetic selection for increased milk production and plasma ghrelin concentration, consistent with the increased appetite reported by Kennedy et al. (2002) and Kolver et al. (2005) in similar cows. Exogenous administration of ghrelin, either centrally or peripherally, has been reported to stimulate growth hormone $(\mathbf{G H})$ secretion, DMI, and body growth and adiposity, and it has been shown to increase milk production in rodent models (Tschop et al., 2000; Nakahara et al., 2003). Ghrelin has also been associated with the regulation of other endocrine functions (Korbonits and Grossman, 2004).

The greatest limitation to milk production in grazing dairy cows is DMI. Kolver and Muller (1998) estimated that $60 \%$ of the difference in milk yield between cows fed fresh pasture and those fed TMR was due to the 
inability of a cow to achieve potential DMI under grazing. Supplementing the diets of cows with starch- or fermentable fiber-based concentrates at pasture is one apparent way to reduce this difference in DMI. However, supplementing the diets of grazing dairy cows with concentrates results in a reduction in time spent grazing (12 min/kg of concentrate DM; Bargo et al., 2003) and a substitution of the supplemented feed for pasture, such that energy intake is not increased to potential. The physiological basis for substitution is poorly understood. Although factors such as unsupplemented pasture DMI, cow BW and genetic merit, and the amount of supplement fed play a role (Grainger and Mathews, 1989; Kennedy et al., 2002; Bargo et al., 2003; Kolver et al., 2005), these factors fail to explain more than $40 \%$ of the variation in substitution rate (Penno, 2002).

We hypothesized that ghrelin may be involved in the reduced appetite of cows receiving ghrelin concentrate supplementation through its role in regulating DMI (Schaller et al., 2003). The main objective of the present study was to investigate the effect of strain of HolsteinFriesian and concentrate feeding level on the plasma ghrelin concentration, and characterize the relationship between plasma ghrelin and production parameters and plasma metabolites associated with energy status.

\section{MATERIALS AND METHODS}

This experiment was conducted at Lye Farm, Dexcel, Hamilton, New Zealand $\left(37^{\circ} 46^{\prime} \mathrm{S} 175^{\circ} 18^{\prime} \mathrm{E}\right)$ during October 2005, and all procedures were approved by the Ruakura Animal Ethics Committee, Hamilton, New Zealand.

\section{Experimental Design}

In July 2004, 58 primiparous and multiparous Holstein-Friesian $(\mathbf{H F})$ cows of 2 genetic strains [North American (NA), $\mathrm{n}=30$; or New Zealand (NZ), $\mathrm{n}=28$ ] were randomly allocated at calving to 1 of 3 supplementary feeding treatments in a $2 \times 3$ factorial arrangement. All cows grazed a generous allowance $(>50 \mathrm{~kg}$ of $\mathrm{DM} /$ cow per d measured to ground level) of fresh pasture and 4 of the 6 groups ( 2 from each strain) received either 3 or $6 \mathrm{~kg}$ of DM/d of a pelleted concentrate. The remaining 2 groups received no concentrates. Treatments were either NZ0, NZ3, NZ6, NA0, NA3, or NA6.

Cow allocation ensured that treatments were balanced for age $(4.6 \pm 1.20 \mathrm{yr})$, DIM (75 $\pm 19.6 \mathrm{~d})$, and breeding worth (a measure of genetic merit accounting for the economic value of the trait; $106 \pm 27.1$; see Harris et al., 1996).

\section{Strains}

The 2 strains compared were either of predominantly NA or NZ ancestry. The NA strain had $>87.5 \%$ NA genetic ancestry. The NA HF cows were either imported as embryos or were direct descendents of the embryos imported. The embryos referred to were imported from the United States and the Netherlands in 1996 by Holland Genetics Ltd. for Livestock Improvement Corporation, New Zealand, as part of their sire-proving scheme. As such, the NA genetics used in the present experiment represent NA genetics that have been used widely in grazing systems.

After birth, progeny of the embryo imports were sold to commercial farmers and were subsequently purchased by Dexcel Ltd. prior to their first parturition. The mean EBV of the sires used were obtained from the Livestock Improvement Corporation, New Zealand, evaluations (May 2005). The mean EBV for the NA animals in the study were $+1,299$ (SD 281.5) $\mathrm{kg}$ of milk, +32 (SD 8.9) kg of fat, +41 (SD 6.3) kg of protein, +86 (SD 14.4) kg of BW, and -15 (SD 107.4) d of survival.

The NZ genetics used in the present experiment were selected from Dexcel herds based on their breeding worth and the proportion of NZ ancestry $(<12.5 \% \mathrm{NA}$ genes). The EBV for the NZ animals in the study were +885 (SD 190.0) kg of milk, +35 (SD 6.0) kg of fat, +33 (SD 5.8) kg of protein, +58 (SD 14.2) kg of BW, and +137 (SD 62.2) d of survival. Each strain represented 6 to 9 sires, which were common across feeding treatments within strain.

\section{Pasture Management and Supplementary Feeding Treatments}

Cows were rotationally grazed as one herd and only returned to the same area when a minimum of 2 leaves had appeared on the majority ( $>75 \%$ ) of perennial ryegrass tillers. Cows had access to a fresh allocation of pasture daily. Pasture allowance $(>50 \mathrm{~kg}$ of DM/cow per d) was sufficient to ensure unrestricted DMI (up to approximately $25 \mathrm{~kg}$ of $\mathrm{DM} / \mathrm{d}$ ) of fresh pasture in the unsupplemented cows. Pasture was of high quality $[\mathrm{CP}=24.1 \pm 1.21 \%$ of $\mathrm{DM}$; OM digestibility $=84.1 \pm$ $1.61 \%$ of $\mathrm{DM} ; \mathrm{NDF}=45.4 \pm 7.14 \%$ of $\mathrm{DM} ; \mathrm{ADF}=22.0$ $\pm 2.01 \%$ of DM; lipids $=4.1 \pm 0.06 \%$ of DM; water-soluble carbohydrates $($ WSC $)=17.9 \pm 5.47 \%$ of $\mathrm{DM} ; \mathrm{ME}=12.7 \pm$ $0.52 \mathrm{MJ} / \mathrm{kg}$ of DM]. Quality was maintained throughout the season, despite high grazing residuals, through strategic use of mowing.

A flat rate of either 3 or $6 \mathrm{~kg}$ of $\mathrm{DM}$ of concentrates (32\% crushed barley, $60 \%$ crushed corn, $2 \%$ broll, $6 \%$ molasses; $\mathrm{CP}=11.3 \pm 0.23 \%$ of $\mathrm{DM} ; \mathrm{NDF}=12.2 \pm 0.78 \%$ of DM; lipids $=2.6 \pm 0.12 \%$ of DM; WSC $=66.1 \pm 0.35 \%$ of DM) was fed individually in the appropriate treat- 
Table 1. Effect of strain (S) of Holstein-Friesian (New Zealand, NZ; or North American, NA) and level of concentrate (C; 0,3 , or $6 \mathrm{~kg}$ of DM/d) supplementation on milk yield (kg/d), milk composition (\%), calculated pasture DMI $(\mathrm{kg} / \mathrm{d}), \mathrm{BW}(\mathrm{kg})$, and $\mathrm{BCS}^{1}$

\begin{tabular}{|c|c|c|c|c|c|c|c|c|c|}
\hline \multirow[b]{2}{*}{ Item } & \multicolumn{2}{|c|}{ Strain } & \multirow[b]{2}{*}{ SEM } & \multicolumn{3}{|c|}{ Concentrate, $\mathrm{kg}$} & \multirow[b]{2}{*}{ SEM } & \multicolumn{2}{|c|}{$P$} \\
\hline & $\mathrm{NZ}$ & NA & & 0 & 3 & 6 & & $\mathrm{~S}$ & $\mathrm{C}$ \\
\hline Milk & 30.0 & 33.5 & 0.73 & 28.6 & 31.9 & 34.7 & 0.88 & $<0.001$ & $<0.001$ \\
\hline Fat & 4.36 & 3.71 & 0.106 & 4.13 & 4.02 & 3.94 & 0.128 & $<0.001$ & 0.56 \\
\hline Protein & 3.47 & 3.32 & 0.040 & 3.29 & 3.41 & 3.50 & 0.048 & $<0.01$ & $<0.01$ \\
\hline Lactose & 4.94 & 4.86 & 0.024 & 4.89 & 4.90 & 4.91 & 0.029 & $<0.05$ & 0.84 \\
\hline $4 \% \mathrm{FCM}$ & 31.6 & 31.7 & 0.85 & 28.7 & 31.6 & 34.6 & 1.02 & 0.85 & $<0.001$ \\
\hline Pasture DMI & 15.6 & 16.1 & 0.39 & 18.2 & 16.1 & 13.3 & 0.47 & 0.36 & $<0.001$ \\
\hline BW & 523 & 542 & 8.6 & 529 & 529 & 539 & 10.4 & 0.10 & 0.71 \\
\hline BCS & 4.5 & 3.9 & 0.09 & 4.1 & 4.3 & 4.2 & 0.11 & $<0.001$ & 0.41 \\
\hline
\end{tabular}

${ }^{1}$ Body condition score units: scale of 1 to 10 .

ments. Concentrate allocation was equally split into 2 feeds daily during milking. For $15 \mathrm{~d}$ precalving, all cows were offered $2 \mathrm{~kg}$ of DM concentrate/d and following calving the NZ3 and NA3 cows received $3 \mathrm{~kg}$ of DM concentrates/d, and the NZ6 and NA6 cows were gradually stepped up to $6 \mathrm{~kg}$ of DM concentrates/d over the following $6 \mathrm{~d}(0.5 \mathrm{~kg}$ of DM concentrates $/ \mathrm{d})$.

\section{Measurements}

Representative samples of pasture were collected daily by hand-plucking pasture to grazing height from paddocks due to be grazed. Samples were bulked weekly, and duplicate samples were dried at either $100^{\circ} \mathrm{C}$, for $\mathrm{DM}$ analysis, or $60^{\circ} \mathrm{C}$ for analysis of nutrient composition. The latter samples were then ground to pass through a 1.0-mm sieve (Christy Lab Mill, Suffolk, UK) and analyzed for CP, NDF, ADF, WSC, fat, ash, and $\mathrm{OM}$ digestibility by near-infrared spectroscopy

Table 2. Number of records, transformed mean $^{1}$ (and SD), backtransformed mean, and CV (\%) for plasma ghrelin $(\mathrm{pg} / \mathrm{mL})$, growth hormone $(\mathrm{GH} ; \mathrm{ng} / \mathrm{mL}), \mathrm{NEFA}(\mathrm{mmol} / \mathrm{L})$, and glucose $(\mathrm{mmol} / \mathrm{L})$ concentrations pre- and postfeeding, and the postprandial change in plasma ghrelin concentration $(\Delta$-ghrelin) in dairy cows 75 and $79( \pm 19.7)$ DIM

\begin{tabular}{|c|c|c|c|c|c|c|}
\hline Variable & Time & $\mathrm{N}$ & $\begin{array}{c}\text { Transformed } \\
\text { mean }\end{array}$ & $\begin{array}{c}\text { Back- } \\
\text { transformed } \\
\text { mean }\end{array}$ & SD & $\mathrm{CV}$ \\
\hline \multirow[t]{3}{*}{ Ghrelin } & Pre & 106 & 5.601 & 270.7 & 0.39 & \\
\hline & Post & 107 & 5.034 & 153.6 & 0.42 & 8 \\
\hline & $\Delta$-Ghrelin & 106 & -0.565 & 117.1 & 0.40 & 71 \\
\hline \multirow{2}{*}{ GH } & Pre & 106 & 0.227 & 1.26 & 0.795 & 350 \\
\hline & Post & 107 & -0.1 & 0.86 & 0.861 & 554 \\
\hline \multirow[t]{2}{*}{ NEFA } & Pre & 114 & -1.721 & 0.18 & 0.882 & 51 \\
\hline & Post & 107 & -2.403 & 0.09 & 0.669 & 28 \\
\hline \multirow[t]{2}{*}{ Glucose } & Pre & 114 & & 3.44 & 0.276 & 8 \\
\hline & Post & 107 & & 2.70 & 0.435 & 16 \\
\hline
\end{tabular}

\footnotetext{
${ }^{1}$ Glucose was not transformed; thus, reported means are in the units of measurement.
}

(Corson et al., 1999). The ME was derived directly from predicted OM digestibility, on the basis of an in vitro cellulase digestibility assay that had been calibrated against in vivo standards (Corson et al., 1999).

Blood was sampled on 2 consecutive weeks during peak lactation (75 and $79 \pm 19.7$ DIM). On both occasions, two $10-\mathrm{mL}$ evacuated blood tubes, (140 IU of sodium heparin and $0.117 \mathrm{~mL}$ of $15 \% \mathrm{~K}_{3}$ EDTA) were collected from each cow by coccygeal venipuncture prior to the a.m. milking (approximately $0730 \mathrm{~h}$ ) and $2 \mathrm{~h}$ following return to pasture (approximately $1000 \mathrm{~h}$ ). Following centrifugation $\left(1,120 \times g, 10 \mathrm{~min}, 4^{\circ} \mathrm{C}\right)$ and extraction, plasma from the EDTA-blood tubes was acidified using $0.1 \mathrm{~N} \mathrm{HCl}$ and treated with phenylmethylsulfonyl fluoride $\left(\mathrm{C}_{7} \mathrm{H}_{7} \mathrm{FO}_{2} \mathrm{~S}\right)$, as per kit instructions (multispecies ghrelin active kit; Linco Research Inc., St. Charles, MO), prior to storage and analysis for plasma acylated ghrelin concentration.

Analyses for NEFA (colorimetric method) and glucose (hexakinase method) were performed on a Hitachi 717 analyzer (Roche, Basel, Switzerland) at $30^{\circ} \mathrm{C}$ by Alpha Scientific Ltd. (Hamilton, New Zealand). The inter- and intraassay coefficients of variation were $<2 \%$ for NEFA and glucose. Plasma GH (Downing et al., 1995) concentrations were measured using a double-antibody RIA with inter- and intraassay coefficients of variation of $<15$ and $10 \%$, respectively. Active (acylated) ghrelin concentrations were measured using a commercially available RIA (Linco Research Inc.; Wertz et al., 2003). The Linco ghrelin (active) assay uses ${ }^{125}$ I-labeled ghrelin and a ghrelin antiserum to determine the level of active ghrelin in serum, plasma, or tissue culture media by the double antibody-polyethylene glycol technique. This assay is specific for the first $11 \mathrm{AA}$ of ghrelin and the octanoyl moiety and has been validated for bovine plasma (Wertz et al., 2003; Wertz-Lutz et al., 2006). Inter- and intraassay coefficients of variation were $<15$ and $10 \%$, respectively. 
Table 3. Correlations within cow test-day among plasma ghrelin, growth hormone (GH), NEFA, and glucose concentrations pre- and postfeeding, and the postprandial change in plasma ghrelin concentration $(\Delta-$ ghrelin) in dairy cows 75 and $79( \pm 19.7)$ DIM

\begin{tabular}{|c|c|c|c|c|c|c|c|c|c|}
\hline \multirow[b]{2}{*}{ Trait } & \multirow[b]{2}{*}{ Time } & \multicolumn{3}{|c|}{ Ghrelin } & \multicolumn{2}{|c|}{ GH } & \multicolumn{2}{|c|}{ NEFA } & \multirow{2}{*}{$\begin{array}{c}\text { Glucose, } \\
\text { Pre }\end{array}$} \\
\hline & & Pre & Post & Change & Pre & Post & Pre & Post & \\
\hline \multirow[t]{2}{*}{ Ghrelin } & Post & $0.51 * * *$ & & & & & & & \\
\hline & $\Delta$-Ghrelin & $-0.43^{* * *}$ & $0.56^{* * * *}$ & & & & & & \\
\hline \multirow[t]{2}{*}{ GH } & Pre & -0.11 & 0.08 & $0.19^{*}$ & & & & & \\
\hline & Post & -0.12 & 0.01 & 0.13 & $0.34 * * *$ & & & & \\
\hline \multirow[t]{2}{*}{ NEFA } & Pre & 0.13 & -0.17 & $-0.31 * *$ & $-0.29 * *$ & $0.20^{*}$ & & & \\
\hline & Post & -0.09 & 0.08 & $0.17 \dagger$ & -0.02 & $0.16 \dagger$ & $0.61 * * *$ & & \\
\hline \multirow[t]{2}{*}{ Glucose } & Pre & $0.24 *$ & $0.17 \dagger$ & -0.05 & -0.16 & -0.14 & 0.09 & -0.03 & \\
\hline & Post & 0.10 & $0.25 * *$ & $0.17 \dagger$ & -0.03 & -0.05 & 0.00 & $0.33^{* * *}$ & $0.20^{*}$ \\
\hline
\end{tabular}

$\dagger P<0.10 ; * P<0.05 ; * * P<0.01 ; * * * P<0.001$.

Individual milk yields were recorded daily (Westfalia Surge, Oelde, Germany) and milk fat, $\mathrm{CP}$, and lactose concentrations were determined by MilkoScan (Foss Electric, Hillerød, Denmark) on individual p.m. and a.m. aliquot samples; the a.m. samples coinciding with the same day as blood sampling. Milk component data were verified by reference techniques for a subset of milk samples (milk fat, Röse-Gottlieb technique; CP, Kjeldahl technique). Body weight and BCS were determined weekly from calving and occurred following the a.m. milking on the day of blood sampling; BCS was assessed on a 10-point scale, where 1 is emaciated and 10 is obese (Macdonald and Roche, 2004).

Mean energy intake was calculated from mean daily milk energy output plus cow maintenance requirements, accounting positively or negatively for BW gain or loss, respectively. A zero energy requirement for pregnancy was assumed. Body weight gain or loss was calculated for each individual cow by calculating the difference in BW between $1 \mathrm{wk}$ presampling and $1 \mathrm{wk}$ postsampling (i.e., over $3 \mathrm{wk}$ ). The efficiency with which energy is used for milk production $\left(\mathrm{k}_{\mathrm{m}}\right)$ was assumed to be $65 \%$, and the maintenance requirement for lactating grazing dairy cows was $0.6 \mathrm{MJ} / \mathrm{kg}$ of $\mathrm{BW}^{0.75}$ (Holmes et al., 2002). The energy required for $1 \mathrm{~kg}$ of $\mathrm{BW}$ gain and the energy supplied from $1 \mathrm{~kg}$ of BW loss were assumed to be 32 and $25 \mathrm{MJ} /$ cow per d, respectively (Holmes et al., 2002). Energy intake was divided by the mean pasture ME concentration to calculate DMI, and pasture DMI was calculated from DMI minus concentrate intake.

\section{DMI $(\mathrm{kg}$ of $\mathrm{DM} / \mathrm{d})=$}

$\left(\frac{\text { milk energy }+ \text { maintenance energy }+ \text { BW gain (or }- \text { BW loss })}{\text { pasture }+ \text { concentrate } \mathrm{ME}}\right)$

\section{Statistical Analysis}

A total of 116 premilking records and 116 postmilking records were available from all 58 cows. Preliminary analysis of all data revealed a positively skewed distribution for ghrelin, GH, and NEFA concentrations. The natural logarithms of all 3 variables were used to normalize the distribution; the Shapiro-Wilk test signified a normal distribution following transformation. The change in ghrelin ( $\Delta$-ghrelin) was calculated as the logarithm of the postprandial sample less the logarithm of the preprandial sample. Hence, a negative value is indicative of a decrease in concentration following feeding. $\Delta$-Ghrelin was normally distributed, as determined using the Shapiro-Wilk test for normality.

The correlations between pre- and postprandial plasma concentrations of ghrelin, GH, NEFA, and glucose within cow test-day were calculated using PROC CORR (SAS Institute, 2006). Correlation analyses were also used to determine the strength of the linear relationship between both pre- and postprandial concentrations with $\Delta$-ghrelin. Graphical examination of all data failed to reveal a nonlinear relationship between the variables investigated. Additional correlation analyses were used to determine the strength of the linear association with production variables and EBV.

Mixed model methodology using PROC MIXED (SAS Institute, 2006) was used to investigate the effects of genetic strain, feed system, parity, DIM, and time of measurement (i.e., pre- or postprandial) on plasma ghrelin, GH, NEFA, and glucose concentrations and $\Delta$ ghrelin using all data. Parity was recoded as $1(n=16)$, $2(n=11)$, or 3 or greater $(n=31)$. A full model was initially created with all main effects and interactions included as classification variables, as well as DIM at sampling included as a continuous variable. Terms were sequentially removed from the model using backward elimination of nonsignificant effects $(P>0.05$ for main effects and $P>0.15$ for interaction terms) based on the $F$-test. Least squares means were extracted from the analysis. Strain and feed system, as well as the interaction between them, were always forced into the model to facilitate the estimation of the respective least 
squares means. Cow was included as a random effect and repeatability of ghrelin, $\Delta$-ghrelin, GH, NEFA, and glucose was estimated as the ratio of the cow variance to the sum of the cow and residual variance.

\section{RESULTS}

The effect of strain and concentrate feeding level on milk production, BCS, BW, and calculated pasture DMI are presented in Table 1. North American cows tended to be heavier $(P<0.10)$ and thinner (lower BCS; $P<$ $0.001)$ at the time of sampling, and they produced more $(P<0.001)$ milk with lower $(P<0.01)$ fat and protein contents. Although not significant, the NA cows consumed numerically more pasture daily.

Table 2 reports the summary statistics for plasma ghrelin, GH, NEFA, and glucose concentrations preand postfeeding, and $\Delta$-ghrelin. All plasma variables declined following feeding, with ghrelin and NEFA concentrations almost halving. The repeatabilities of ghrelin, $\Delta$-ghrelin, GH, NEFA, and glucose across DIM were $0.52,0.27,0.30,0.34$, and 0.16 , respectively.

Pearson correlations among plasma ghrelin, GH, NEFA, and glucose concentrations, and $\Delta$-ghrelin within cow test-day are presented in Table 3. Prefeeding plasma ghrelin concentrations were positively correlated with plasma ghrelin concentrations postfeeding but negatively associated with $\Delta$-ghrelin, indicating a greater postprandial decline in plasma ghrelin concentration but still a higher postprandial plasma ghrelin concentration when prefeeding concentrations were high. Similar relationships between pre- and postfeeding were observed for plasma GH, NEFA, and glucose, with concentrations declining postprandially. Higher prefeeding plasma ghrelin concentrations were also associated with higher prefeeding plasma glucose concentrations but were not significantly correlated with either prefeeding plasma GH or NEFA concentrations.

Pre- and post feeding plasma GH concentrations were positively associated with each other, but were negatively and positively associated, respectively, with prefeeding plasma NEFA concentrations. Results indicate a reduced plasma NEFA concentration prefeeding in cows with elevated prefeeding plasma GH, but reflect a greater postprandial GH in cows with greater prefeeding NEFA. The direction of these relationships is similar but is nonsignificant postfeeding, reflecting the positive relationship within NEFA and GH measures preand postfeeding.

Prefeeding plasma ghrelin concentrations were not related to calculated DMI, milk production, BCS, or BW (Table 4). However, postfeeding ghrelin concentrations and $\Delta$-ghrelin were negatively associated with calculated DMI, yield of milk, and milk constituents. This

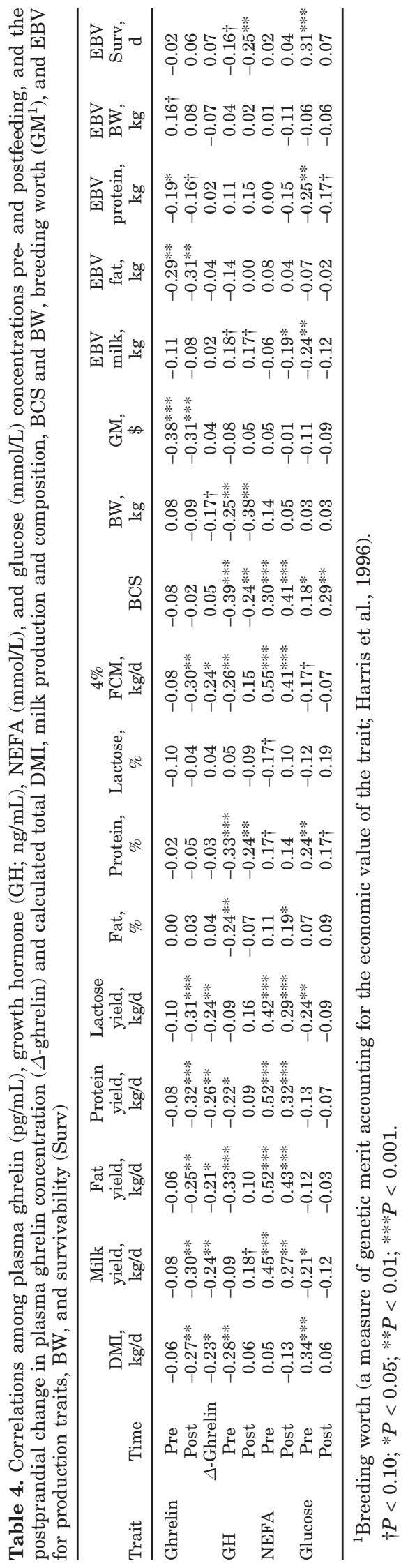


indicates an increase in calculated DMI, milk yield, and milk constituents either when the postprandial ghrelin concentration was low or when the postprandial decline in ghrelin increased. Prefeeding GH concentrations were negatively correlated with calculated DMI, milk component yield, milk composition, BCS, and BW, whereas postfeeding GH concentrations were positively correlated $(P<0.10)$ with milk yield but negatively correlated with milk protein percentage, BCS, and BW, indicating greater milk yield and lower BCS and BW with increasing postfeeding plasma GH. Elevated plasma NEFA concentrations, both prior to and after feeding, were associated with greater milk production and heavier, fatter cows. Plasma glucose concentrations prefeeding were negatively correlated with milk production variables.

The relationships between plasma ghrelin concentrations and the EBV for production and nonproduction traits are presented in Table 4. Cows genetically superior for profitability (i.e., higher breeding worth; Harris et al., 1996) under grazing systems had lower $(P<0.05)$ plasma ghrelin concentrations pre- and postfeeding. Furthermore, cows of high genetic merit for fat and protein yields had lower ghrelin concentrations preand postfeeding. The prefeeding plasma ghrelin concentration was positively correlated with EBV for BW, indicating a higher plasma ghrelin in genetically heavier cows.

Plasma GH concentrations were positively associated with the EBV for milk yield and negatively associated with cow survivability. In comparison, plasma glucose concentrations were negatively correlated with the EBV for both milk yield and protein yield, but were positively associated with cow survivability. Most of the remaining indicators of genetic merit were not significantly associated with plasma ghrelin, GH, NEFA, or glucose concentrations.

The effect of HF strain, feeding system, and timing of sampling relative to feeding, as well as significant interactions on the measured blood metabolites and hormones, are summarized in Table 5. No significant strain $\times$ feeding system interaction existed for any of the traits analyzed. Parity did not significantly $(P>$ 0.05 ) affect any of the blood measurements. Across the DIM represented in the present data set (26 to $106 \mathrm{~d}$ ), a linear negative effect of DIM was observed for plasma NEFA concentrations, indicating a decrease in plasma NEFA as DIM increased; DIM did not significantly affect any of the other blood measures.

North American HF cows tended $(P<0.10)$ to have greater plasma ghrelin and GH concentrations than did their NZ contemporaries. Strain did not significantly affect blood glucose or NEFA concentrations. There was an interaction between feeding system and timing of sampling relative to feeding in plasma concentrations of ghrelin and NEFA. There was no evident effect of concentrate supplementation on plasma ghrelin concentration prior to feeding, but there was a linear decline in postfeeding concentrations and a concomitant increase in $\Delta$-ghrelin as the concentrate amount increased. The opposite effect of sampling time was evident in plasma NEFA. Concentrate supplementation was associated with a linear increase in the plasma NEFA concentration prefeeding, but there was no difference in postfeeding NEFA concentrations. All plasma variables were reduced $(P<0.001)$ following feeding.

\section{DISCUSSION}

Very little is known about the effect of ghrelin on DMI in dairy cows (Robinson et al., 2006), other than that cows exhibit a postprandial decline in blood (Hayashida et al., 2001; Roche et al., 2006b), consistent with other species (Sugino et al., 2002, 2004); that its concentration in blood is greatest in early lactation and declines as lactation progresses (Itoh et al., 2006), consistent with the lactational decline in DMI; and that the concentration in blood has increased with increasing genetic merit selection for milk production (Roche et al., 2006b). These results suggest that ghrelin may have causative or exigenic effects in dairy cows, similar to those reported in rodents (Nakazato et al., 2001; Nakahara et al., 2003) and humans (Wren et al., 2001; Neary et al., 2004). However, no data are available as yet either to substantiate or to refute this hypothesis.

Although ghrelin concentration was elevated prefeeding and declined postfeeding, as reported by Hayashida et al. (2001) in goats and Sugino et al. (2002) in sheep, the presented correlation coefficients appear inconsistent with the orexigenic effect of exogenously administered ghrelin (Tschop et al., 2004). Prefeeding ghrelin concentrations were unrelated to either calculated DMI or milk production, consistent with a lack of effect of macronutrients on preprandial ghrelin (Paul et al., 2005), but postfeeding ghrelin concentrations and $\Delta$ ghrelin displayed inexplicable negative relationships, with calculated DMI remaining high in cows with a greater postprandial decline in plasma ghrelin. This may simply reflect an as yet unidentified compensatory mechanism(s) within the animal that significantly influences appetite. The very low circulating concentrations of ghrelin in obese humans (Tschop et al., 2001), where subjects continue to eat even though the ghrelin stimulus is muted through nutrient satiety, or the elevated ghrelin concentrations in patients suffering from anorexia nervosa (Nakai et al., 2003) is consistent with such an overriding compensatory mechanism. 
Table 5. Least squares means (back-transformed LSM in parentheses) for strain of Holstein-Friesian dairy cow (New Zealand, NZ; and North American, NA), concentrate feeding level, and sample time relative to feeding on plasma ghrelin $(\mathrm{pg} / \mathrm{mL})$, growth hormone $(\mathrm{GH}, \mathrm{ng} / \mathrm{mL})$, NEFA $(\mathrm{mmol} / \mathrm{L})$, and glucose $(\mathrm{mmol} / \mathrm{L})$ concentrations in dairy cows 75 and $79( \pm 19.7)$ DIM $^{1}$

\begin{tabular}{|c|c|c|c|c|c|c|}
\hline Effect & Group & & Ghrelin & GH & NEFA & Glucose $^{2}$ \\
\hline \multirow[t]{4}{*}{ Strain } & $\mathrm{NZ}$ & & $5.25(190)$ & $-0.043(0.96)$ & $-2.04(0.130)$ & 3.09 \\
\hline & NA & & 5.39 (219) & $0.269(1.31)$ & $-2.17(0.114)$ & 3.04 \\
\hline & SE & & 0.062 & 0.113 & 0.082 & 0.044 \\
\hline & $P$-value & & 0.09 & 0.04 & 0.24 & 0.41 \\
\hline \multirow[t]{5}{*}{ Concentrate } & $0 \mathrm{~kg}$ & & & 0.176 (1.19) & & 2.99 \\
\hline & $3 \mathrm{~kg}$ & & & $0.058(1.06)$ & & 3.13 \\
\hline & $6 \mathrm{~kg}$ & & & $0.104(1.11)$ & & 3.08 \\
\hline & $\mathrm{SE}$ & & & 0.14 & & 0.05 \\
\hline & $P$-value & & 0.41 & 0.82 & 0.20 & 0.15 \\
\hline \multirow[t]{4}{*}{ Timing } & Pre & & & $0.304(1.36)$ & & 3.44 \\
\hline & Post & & & $-0.078(0.92)$ & & 2.69 \\
\hline & $\mathrm{SE}$ & & & 0.10 & & 0.04 \\
\hline & $P$-value & & $<0.001$ & $<0.001$ & $<0.001$ & $<0.001$ \\
\hline \multirow[t]{9}{*}{$\begin{array}{l}\text { Timing } \times \\
\text { concentrate }\end{array}$} & Status & $\begin{array}{c}\text { Concentrate, } \\
\mathrm{kg}\end{array}$ & Ghrelin & $\mathrm{GH}$ & NEFA & Glucose $^{2}$ \\
\hline & Prefeeding & 0 & $5.63(278)$ & & $-2.02(0.13)$ & \\
\hline & Prefeeding & 3 & $5.53(253)$ & & $-1.84(0.16)$ & \\
\hline & Prefeeding & 6 & $5.62(276)$ & & $-1.46(0.23)$ & \\
\hline & Postfeeding & 0 & $5.17(176)$ & & $-2.37(0.09)$ & \\
\hline & Postfeeding & 3 & $5.03(153)$ & & $-2.46(0.09)$ & \\
\hline & Postfeeding & 6 & 4.93 (138) & & $-2.47(0.09)$ & \\
\hline & $\mathrm{SE}$ & & 0.082 & & 0.114 & \\
\hline & $P$-value & & $<0.05$ & 0.16 & $<0.001$ & 0.39 \\
\hline
\end{tabular}

${ }^{1}$ Transformed LSM and mean SE are presented.

${ }^{2}$ Glucose was not transformed; thus, reported means are in the units of measurement.

However, the lack of association between $\mathrm{GH}$ and ghrelin, a known GH secretagogue, in the current study and the negative association between plasma GH and calculated DMI and milk production when exogenous administration of bST has been shown to increase both parameters (Bauman, 1999) also reflects the deficiencies of correlation analyses in separating association and causation effects. A factor possibly contributing to these discrepancies may be that the correlations were estimated across strains and feeding systems, although adjustment of the plasma ghrelin concentration for the feeding system did not change the direction of the correlation. We observed a similar type of discrepancy when examining the effect of strain on BCS and BCS change, reporting significantly greater BCS at calving and less BCS loss postcalving in NZ compared with NA cows (Roche et al., 2006a), even though separate correlation analyses indicated greater BCS loss postpartum in cows of higher BCS at calving (Roche et al., 2007).

The positive correlation between pre- and postfeeding plasma glucose and pre- and postfeeding plasma ghrelin is consistent with recent findings in which exogenous administration of ghrelin to dairy cows resulted in an increase in blood glucose, probably through a positive influence of ghrelin on cortisol secretion (Itoh et al., 2006).
The increase in milk production in NA cows has been reported by others (Horan et al., 2005; Kolver et al., 2005; Roche et al., 2006a), and the greater plasma ghrelin concentration in NA cows is supported by recent results indicating an increase in appetite and in both pre- and postprandial plasma ghrelin concentrations in dairy cows genetically selected for superior milk production (Roche et al., 2006b). As an HF strain, NA cows have been more intensely selected for increased milk production than NZ HF (Harris and Kolver, 2001; Horan et al., 2005), and in the present study the NA HF strain had greater EBV for milk yield ( $+1,299$ vs. $+885 \mathrm{~kg}$ of milk for NA and NZHF, respectively) and produced more milk (33.5 vs. $30.0 \mathrm{~kg}$ of milk/d for NA and NZHF, respectively). The tendency toward greater calculated DMI and milk production in NA cows and the associated elevated plasma ghrelin concentration is consistent with the reported orexigenic effect of exogenous ghrelin in monogastric models (Nakazato et al., 2001; Wren et al., 2001; Nakahara et al., 2003; Neary et al., 2004). Nakahara et al. (2003) also reported increased BW gain and milk yield in rats injected with ghrelin twice daily. Based on these findings and the apparent positive relationships among NA HF strain, ghrelin, calculated DMI, and milk production in the current study, further research in dairy cows is re- 
quired to determine whether exogenously administered ghrelin increases DMI and milk production.

The effect of concentrate supplementation on circulating ghrelin concentrations following $2 \mathrm{~h}$ of unrestricted access to pasture in all cows is noteworthy. When the diets of grazing cows are supplemented with concentrates, grazing time declines, on average, by 12 $\mathrm{min} / \mathrm{kg}$ of DM concentrates (Bargo et al., 2003), leading to a reduction in pasture intake (Table 2 ). This decline in pasture intake when supplements are offered to grazing cows is termed substitution; substitution rate is the decline in pasture intake relative to the amount of supplement consumed (Bargo et al., 2003). Although research has identified factors associated with substitution rate, such as pasture allowance, cow BW and genetic merit, supplement type, and supplement amount, less than $40 \%$ of the variation in the substitution rate can be attributed to these physical features (Penno, 2002).

However, the linear decline in postprandial ghrelin concentration with increasing concentrate supplementation, and the associated decline in pasture intake signifies that substitution may, at least in part, be neurologically controlled. The hypothalamus has long been recognized as a crucial interface between afferent peripheral signals, other regulatory centers in the central nervous system, and efferent pathways jointly regulating energy balance (Tschop et al., 2004). Consistent with this, ghrelin's orexigenic mode of action is through stimulation of hypothalamic neuropeptide neurons, such as orexin and neuropeptide Y (Bagnasco et al., 2003; Kojima and Kangawa, 2005), and through agoutirelated protein (Chen et al., 2004). The decline in postprandial plasma ghrelin with increasing supplementation would therefore be expected to result in an attenuated appetite, and a reduction in time spent grazing.

How concentrate supplementation influences the circulating ghrelin concentration is not known. Ghrelin is produced primarily in the oxyntic glands of the abomasum in ruminants (Hayashida et al., 2001). However, physical sensations alone are not responsible for the meal-regulation of circulating ghrelin, with little effect of gastric distention on circulating plasma ghrelin concentrations (Williams et al., 2003; Overduin et al., 2005). Consistent with the results presented here, research in humans has shown no effect of macronutrient type on preprandial ghrelin concentrations (Paul et al., 2005). However, what controls the postprandial decline in plasma ghrelin remains unclear. Infusions of glucose into either the stomach, the duodenum, or the jejunum of rats (Williams et al., 2003; Overduin et al., 2005), or venous administration of glucose in humans (Schaller et al., 2003) and cows (J. R. Roche, unpublished data) have all been reported to reduce ghrelin in a manner similar to that observed when either glucose, AA, or lipids were infused into the stomach, duodenum, or jejunum, reflecting a nonnutrient-specific attenuation of ghrelin production postprandially.

However, the mechanism by which nutrients reduce blood ghrelin is not known. Recent results implicate a postprandial rise in insulin with declining ghrelin (Blom et al., 2005). Increasing the concentrate proportion of the diet in grazing cows would increase the propionate portion of VFA absorbed from the rumen (Van Soest, 1994). It is possible that increased ruminal propionate production may be responsible for the decline in circulating ghrelin in dairy cows, either directly or through increased gluconeogenesis (Fahey and Berger, 1988) or insulin secretion (Sano et al., 1993), thereby reducing appetite, time spent grazing, and pasture intake. Further research is required to determine the mechanism by which ghrelin is reduced postprandially, and to test whether additional ghrelin would reduce the negative effects of supplements on pasture intake.

\section{CONCLUSIONS}

Although the correlations reported in the present study did not depict a direct relationship between endogenous ghrelin production and either DMI or milk production, the greater plasma ghrelin concentration in NA HF compared with NZ HF and the reduction in circulating ghrelin with increasing concentrate supplementation suggest an orexigenic effect of ghrelin in grazing dairy cows. The negative effect of concentrate supplementation on plasma ghrelin offers, at least in part, a neuroendocrine basis for the reduction in pasture intake when grazing dairy cows are offered supplements.

\section{ACKNOWLEDGMENTS}

The authors acknowledge the technical assistance of J. Lee, K. Watkins, P. Gore, and P. Aspin, all the help afforded them by Dexcel's Lye dairy farm staff, and the laboratory expertise of Alpha Scientific (Hamilton, New Zealand). The GH used in the RIA assay was kindly gifted through the National Hormone and Peptides Program, National Institute of Diabetes and Digestive and Kidney Diseases (Torrance, CA), and A. F. Parlow. This work was funded by New Zealand Dairy Farmers, through the Dairy InSight research fund.

\section{REFERENCES}

Bagnasco, M., G. Tulipano, M. R. Melis, A. Argiolas, D. Cocchi, and E. E. Muller. 2003. Endogenous ghrelin is an orexigenic peptide acting in the arcuate nucleus in response to fasting. Regul. Pept. 111:161-167. 
Bargo, F., L. D. Muller, E. S. Kolver, and J. E. Delahoy. 2003. Invited review: Production and digestion of supplemented dairy cows on pasture. J. Dairy Sci. 86:1-42.

Bauman, D. E. 1999. Bovine somatotropin and lactation: From basic science to commercial application. Domest. Anim. Endocrinol. 17:101-116.

Blom, W. A. M., A. Stafleu, C. de Graaf, F. J. Kok, G. Schaafsma, and H. F. J. Hendriks. 2005. Ghrelin response to carbohydrateenriched breakfast is related to insulin. Am. J. Clin. Nutr. 81:367-375.

Broberger, C. 2005. Brain regulation of food intake and appetite: Molecules and networks. J. Intern. Med. 258:301-327.

Chen, H. Y., M. E. Trumbauer, A. S. Chen, D. T. Weingarth, J. R. Adams, E. G. Frazier, Z. Shen, D. J. Marsh, S. D. Feighner, X.M. Guan, Z. Ye, R. P. Nargund, R. G. Smith, L. H. T. Van Der Ploeg, A. D. Howard, D. J. MacNeil, and S. Qian. 2004. Orexigenic action of peripheral ghrelin is mediated by neuropeptide $\mathrm{Y}$ and agouti-related protein. Endocrinology 145:2607-2612.

Corson, D. G., G. C. Waghorn, M. J. Ulyatt, and J. Lee. 1999. NIRS: Forage analysis and livestock feeding. Proc. N. Z. Grassl. Assoc. 61:127-132.

Downing, J. A., J. Joss, P. Connel, and R. J. Scaramuzzi. 1995. Ovulation rate and the concentration of gonadotrophic and metabolic hormones in ewes fed lupin grain. J. Reprod. Fertil. 103:137-145.

Fahey, G. C., and L. L. Berger. 1988. Carbohydrate nutrition of ruminants. Pages 269-297 in The Ruminant Animal: Digestive Physiology and Nutrition. D. C. Church, ed. Prentice-Hall, Englewood Cliffs, NJ.

Grainger, C., and G. L. Mathews. 1989. Positive relation between substitution rate and pasture allowance for cows receiving concentrates. Aust. J. Exp. Agric. 29:355-360.

Harris, B. L., J. M. Clark, and R. G. Jackson. 1996. Across breed evaluation of dairy cattle. Proc. N. Z. Soc. Anim. Prod. 56:12-15.

Harris, B. L., and E. S. Kolver. 2001. A review of Holsteinization on intensive pastoral dairy farming in New Zealand. J. Dairy Sci. 84(E Suppl.):E56-E61.

Hayashida, T., K. Murakami, K. Mogi, M. Nishihara, M. Nakazato, M. S. Mondal, Y. Horii, M. Kojima, K. Kangawa, and N. Murakami. 2001. Ghrelin in domestic animals: Distribution in stomach and its possible role. Domest. Anim. Endocrinol. 21:17-24.

Holmes, C. W., I. M. Brookes, D. J. Garrick, D. D. S. Mackenzie, T. J. Parkinson, and G. F. Wilson. 2002. Nutrition: Quantitative requirements for dairy cattle. Pages 235-262 in Milk Production from Pasture. Massey University Press, Palmerston North, New Zealand.

Horan, B., P. Dillon, D. P. Berry, P. O'Connor, and M. Rath. 2005. The effect of strain of Holstein-Friesian, feeding system and parity on lactation curves characteristics of spring-calving dairy cows. Livest. Prod. Sci. 95:231-241.

Itoh, F., T. Komatsu, S. Kushibiki, and K. Hodate. 2006. Effects of ghrelin injection on plasma concentrations of glucose, pancreatic hormones and cortisol in Holstein dairy cattle. Comp. Biochem. Physiol. A: Mol. Integr. Physiol. 143:97-102.

Kennedy, J., P. Dillon, P. Faverdin, L. Delaby, F. Buckley, and M. Rath. 2002. The influence of cow genetic merit on response to concentrate supplementation in a grass based system. J. Anim. Sci. 75:433-446.

Kobelt, P., S. Helmling, A. Stengel, B. Wlotzka, V. Andresen, B. F. Klapp, B. Wiedenmann, S. Klussmann, and H. Mönnikes. 2006. Anti-ghrelin Spiegelmer NOX-B11 inhibits neurostimulatory and orexigenic effects of peripheral ghrelin in rats. Gut 55:788-792.

Kojima, M., and K. Kangawa. 2005. Ghrelin: Structure and function. Physiol. Rev. 85:495-522.

Kolver, E. S., and L. D. Muller. 1998. Performance and nutrient intake of high producing Holstein cows consuming pasture or a total mixed ration. J. Dairy Sci. 81:1403-1411.

Kolver, E. S., J. R. Roche, C. R. Burke, and P. W. Aspin. 2005. Influence of dairy cow genotype on milk solids, body condition and reproduction response to concentrate supplementation. Proc. N. Z. Soc. Anim. Prod. 65:46-52.
Korbonits, M., and A. B. Grossman. 2004. Non-growth hormone endocrine actions of ghrelin. Pages 73-89 in Ghrelin. E. Ghigo, ed. Kluwer Academic Publishers, Boston, MA.

Macdonald, K. A., and J. R. Roche. 2004. Condition scoring made easy: Condition scoring dairy herds. 1st ed. Dexcel Ltd., Hamilton, New Zealand.

Nakahara, K., T. Hayashida, M. Nakazato, M. Kojima, H. Hosoda, K. Kangawa, and N. Murakami. 2003. Effect of chronic treatments with ghrelin on milk secretion in lactating rats. Biochem. Biophys. Res. Commun. 303:751-755.

Nakai, Y., H. Hosoda, K. Nin, C. Ooya, H. Hayashi, T. Akamizu, and K. Kangawa. 2003. Plasma levels of active form of ghrelin during oral glucose tolerance test in patients with anorexia nervosa. Eur. J. Endocrinol. 149:R1-R3.

Nakazato, M., N. Murakami, Y. Date, M. Kojima, H. Motsua, K. Kangawa, and S. Matsukura. 2001. A role for ghrelin in the central regulation of feeding. Nature 409:194-198.

Neary, N. M., C. J. Small, A. M. Wren, J. L. Lee, M. R. Druce, C. Palmieri, G. S. Frost, M. A. Ghatei, R. C. Coombes, and S. R. Bloom. 2004. Ghrelin increases energy intake in cancer patients with impaired appetite: Acute, randomized, placebo-controlled trial. J. Clin. Endocrinol. Metab. 89:2832-2836.

Overduin, J., R. S. Frayo, H. J. Grill, J. M. Kaplan, and D. E. Cummings. 2005. Role of the duodenum and macronutrient type in ghrelin regulation. Endocrinology 146:845-850.

Paul, D. R., M. Kramer, D. G. Rhodes, and W. V. Rumpler. 2005. Preprandial ghrelin is not affected by macronutrient intake, energy intake or energy expenditure. J. Negat. Results Biomed. 4:1-8.

Penno, J. W. 2002. The response by grazing dairy cows to supplementary feeds. PhD Thesis. Massey University, Palmerston North, New Zealand.

Robinson, J. J., C. J. Ashworth, J. A. Rooke, L. M. Mitchell, and T. G. McEvoy. 2006. Nutrition and fertility in ruminant livestock. Anim. Feed Sci. Technol. 126:259-276.

Roche, J. R., D. P. Berry, and E. S. Kolver. 2006a. Holstein-Friesian strain and feed effects on milk production, body weight, and body condition score profiles in grazing dairy cows. J. Dairy Sci. 89:3532-3543.

Roche, J. R., K. A. Macdonald, C. R. Burke, J. M. Lee, and D. P. Berry. 2007. Associations among body condition score, body weight, and reproductive performance in seasonal-calving dairy cattle. J. Dairy Sci. 90:376-391.

Roche, J. R., A. J. Sheahan, L. M. Chagas, and D. P. Berry. 2006b. Genetic selection for milk production increases plasma ghrelin concentration in pasture-based dairy cows. J. Dairy Sci. 89:3471-3475.

Sano, H., N. Hattori, Y. Todome, J. Tsuruoka, H. Takahashi, and Y. Terashima. 1993. Plasma insulin and glucagon responses to intravenous infusion of propionate and their autonomic control in sheep. J. Anim. Sci. 71:3414-3422.

SAS Institute. 2006. User's Guide Version 9.1: Statistics. SAS Institute, Cary, NC.

Schaller, G., A. Schmidt, J. Pleiner, W. Woloszczuk, M. Wolzt, and A. Luger. 2003. Plasma ghrelin concentrations are not regulated by glucose or insulin: A double-blind, placebo-controlled crossover clamp study. Diabetes 52:16-20.

Seeley, R. J., D. A. D’Alessio, and S. C. Woods. 2004. Fat hormones pull their weight in the CNS. Nat. Med. 10:454-455.

Sugino, T., Y. Hasegawa, Y. Kikkawa, J. Yamaura, M. Yamagishi, Y. Kurose, M. Kojima, K. Kangawa, and Y. Terashima. 2002. A transient surge of ghrelin secretion before feeding is modified by different feeding regimens in sheep. Biochem. Biophys. Res. Commun. 298:785-788.

Sugino, T., Y. Hasegawa, Y. Kurose, M. Kojima, K. Kangawa, and Y. Terashima. 2004. Effects of ghrelin on food intake and neuroendocrine function in sheep. Anim. Reprod. Sci. 82-83:183-194.

Tschop, M., T. Castaneda, and U. Pagotto. 2004. Ghrelin, food intake and energy balance. Pages 91-111 in Ghrelin. E. Ghigo, ed. Kluwer Academic Publishers, Boston, MA.

Tschop, M., D. L. Smiley, and M. L. Heiman. 2000. Ghrelin induces adiposity in rodents. Nature 407:908-913. 
Tschop, M., C. Weyer, P. A. Tataranni, V. Devanarayan, E. Ravussin, and M. L. Heimen. 2001. Circulating ghrelin levels are decreased in human obesity. Diabetes 50:707-709.

Van Soest, P. J. 1994. Microbes in the gut. Pages 253-280 in Nutritional Ecology of the Ruminant. 2nd rev ed. Cornell University Press, Ithaca, NY.

Wertz, A. E., T. J. Knight, C. G. Ribeiro-Filho, D. C. Beitz, and A. Trenkle. 2003. Validation of a ghrelin radioimmunoassay (RIA) for use in evaluating physiological factors that influence plasma ghrelin concentrations in beef cattle. J. Anim. Sci. 81(Suppl. 1):95. (Abstr.)
Wertz-Lutz, A. E., T. J. Knight, R. H. Pritchard, J. A. Daniel, J. A. Clapper, A. J. Smart, A. Trenkle, and D. C. Beitz. 2006. Circulating ghrelin concentrations fluctuate relative to nutritional status and influence feeding behavior in cattle. J. Anim. Sci. 84:32853300 .

Williams, D. L., D. E. Cummings, H. J. Grill, and J. M. Kaplan. 2003. Meal-related ghrelin suppression requires post-gastric feedback. Endocrinology 144:2765-2767.

Wren, A. M., L. J. Seal, M. A. Cohen, A. E. Brynes, G. S. Frost, K. G. Murphy, W. S. Dhillo, M. A. Ghatei, and S. R. Bloom. 2001. Ghrelin enhances appetite and increases food intake in humans. J. Clin. Endocrinol. Metab. 86:5992-5995. 